\title{
Christina Georgina Rossetti (1830-1894)
}

\author{
Magdalena López PÉrez \\ Universidad de Córdoba
}

Christina Georgina Rossetti, una de las poetisas inglesas más importantes de la época victoriana, cuyos poemas pueden, en ocasiones, compararse a los de Elizabeth Barrett Browning, nació en 1830 en Londres, en el seno de una familia intimamente relacionada con las artes. Aunque sus ideales religiosos estaban más cercanos a su madre, heredó, pese a ser la más joven de una importante y reconocida familia de poetas, artistas y críticos muchas de las tendencias artísticas de su padre. Como algún reputado crítico de su obra ha señalado,

\begin{abstract}
"Christina Rossetti was the least intellectual of the family of two girls and two boys. She and her sister, Maria, were educated by their mother and they were encouraged to follow Anglo-Catholicism" .
\end{abstract}

Publicó algunos de sus primeros poemas con el pseudónimo de Ellen Alleyne en The Germ (1850), una revista prerrafaelista, y posó como modelo para su hermano, Dante Gabriel Rossetti, y otros pintores prerrafaelistas.

Por su educación familiar, hablaba, al igual que su hermano Dante Gabriel, italiano y portugués a la perfección. Compuso desde temprana edad y pese a que su abuelo publicó privadamente sus primeros versos en 1847 , no publicaría su primer libro hasta la aparición de Goblin Market and Other Poems (1862), un gran éxito no sólo a nivel personal sino también extensible al grupo prerrafaelista. Gran parte de su obra es de carácter religioso, donde muestra su gran y profundo amor a Cristo, motivo que marca de manera decisiva toda su producción literaria, sobre todo en los últimos años. Asimismo, también trata los temas de la renuncia al amor terrenal y la preocupación por la muerte, que se esbozan en poemas como "Song" y "UpHill". Otros poemas, como "A Birthday", son terrenales, románticos y sensuales. La obra de Rossetti abarca una amplia variedad de estilos y formas: sus baladas, sonetos, poemas de amor, rimas de estilo y versos disparatados son producto de una inteligencia consumada.

Tras dos compromisos fallidos, en 1850 con el pintor prerrafaelista John Collison por las diferencias de carácter religioso que primaban entre ellos (èl católico y ella anglicana) y en 1866, con Charles Bagot Cayley, rechazado por ser agnóstico, Rossetti nunca se casó. Por el contrario, dedicó gran parte de su vida al retito en un convento, donde pasó quince años dedicándose a las buenas acciones y a la meditación religiosa, aunque parece ser que durante este tiempo estuvo unida sentimentalmente al poeta William Bell Scott. En 
esa época, Rossetti escribió magníficos poemas infantiles, como los contenidos en Sing-song: A Nursery Rhyme Book (1872), con ilustraciones de Arthur Hughes. Lo mejor de su poesía es Goblin Market (1862) y The Prince's Progress and Other Poems (1866).

En 1871 cayó gravemente enferma y ya no se recuperaría. Tras SingSong no volvería a publicar hasta 1881 , fecha en la que edita $A$ Pageant and Other Poems. Su poesia se vuelve cada vez más religiosa y alejada del mundo que la rodea. Se muestra ahora como una poeta melancólica, obsesionada con la muerte y centrada principalmente en la producción de una prosa devota, como Time Flies (1885). Siete años más tarde, en 1892, apareció The Face of the Deep: A Devotional Commentary on the Apocalypse, suma de las preocupaciones religiosas y sociales de su tiempo, en la que la autora meditaba acerca de la prostitución, el desempleo, la vivisección y la indigencia. Al año siguiente publicó su última obra, Verses. Rossetti estaba propuesta para recibir una alta condecoración de las letras de su país, pero no pudo gozar de este reconocimiento ya que murió el 29 de diciembre de ese mismo año, en 1894, de cáncer, en Londres, el mismo lugar que la vivió nacer. Un último libro, New Poems, publicado y editado tras su muerte en 1896 por su hermano William Michael Rossetti, contenía los últimos poemas inéditos de Rossetti. En 1904, William publicó sus obras completas.

La mejor definición de la poesía de Rossetti y su manera de escribir son las siguientes palabras de su hermano William, bastante significativas:

\begin{abstract}
"Christina's habits of composing were eminently of the spontaneous kind. I question her having ever once deliberated with herself whether or not she would write something or other, and then, alter thinking out a subject, having proceeded to treat it in regular spells of work. Instead of this, something impelled her feelings, or came into her head, and her hand obeyed the dictation. I suppose she scribbled lines off rapidly enough, and afterwards took whatever amount of pains she deemed requisite for keeping them in right form and expression"?
\end{abstract}

Sus poemas son tan intensos como los de su hermano Dante Gabriel Rossetti, aunque mucho más simples, siendo esta autora completamente ortodoxa en su definido dualismo de naturaleza y espiritu. Pese a carecer de yuxtaposición dramática, bastante abundante en Hopkins, crea un tipo de poesia devota bastante original e innovadora, ya que produce el efecto de estar alejada del miedo y la timidez.

Rossetti es más conocida por sus baladas y su lírica místico-religiosa. Su poesía está marcada por el simbolismo y la delicadeza e intensidad con la que 
expresa sus propios sentimientos, aunque la mayoría de ella es bastante reducida y repetitiva en los temas empleados. Poseyó una de las técnicas más sutiles de toda la poesia inglesa, ya que dejaba escondida gran parte de las características básicas del Prerrafaelismo, en medio de un discurso sencillo, basado principalmente en el habla diaria, donde, al contrario que su hermano, no había grandes sonoridades ni préstamos, sino más bien un fiel retrato de sus problemas y dolores.

En Christina Rossetti se da siempre la recreación de un paraíso, el cristiano, donde todos los sueños se verán cumplidos en su unión con Dios. Para ella, sólo el mundo de los niños es el refugio hacia el que volverse buscando un mundo terrenal, rodeado de hadas buenas, donde los bajos deseos no tendrán lugar. De manera parecida pasa del amor corporal a un amor intensamente sentido por la figura de Jesucristo, en el que confiesa su pasión con los mismos términos que podría haberlo hecho a un hombre. En muy pocos momentos Christina tuvo el valor suficiente para que sus poemas religiosos, que forman la mayor parte de su producción, dejaran de ser una entonación desesperada de amor o de auto-humillación.

Pero siempre hace su aparición el fracaso que empieza con su propia desestimación y termina siempre en la muerta, en el canto melancólico de su propia muerte. En esta poeta se cumple, más que en ningún otro poeta del prerrafaelismo, el sentimiento de otoño, de niebla y de hojas secas, que sólo ocasionalmente rompe un grito medio desgarrado.

Como hemos señalado anteriormente, Rossetti es una poetisa triste. La mayoría de sus poemas hablan de desengaño o pérdida. Como muchas poetisas, Rossetti parece inclinarse hacia el lado más oscuro de la vida. Sin embargo, en ciertas ocasiones, también aparecen poemas de tono alegre, como "A Birthday".

Asimismo, en el poema "Spring", podemos observar toda la fuerza de Rossetti: la exactitud en la observación ("cleft swallows"), la felicidad de un corazón que goza en la multitud de los objetos naturales, etc.

Es difícil hacer una selección de su poesía, ya que muchos poemas son de la misma temática. Al igual que otras poetisas, como Emily Dickinson y Charlotte Mew, Christina Rossetti siempre se mantiene cercana a la melancolía. A través de la temática de la muerte produjo las más hermosas canciones del siglo XIX en Inglaterra. Todo le sirvió de motivo para crear música, como ejemplifica el soneto "Remember" y la canción que con tema parecido escribió a uno de sus pretendientes.

Como W.W. Robson comenta:

"So hard is it to over-praise the beauty and purity of Christina Rossetti's writings that there must be a strong temptation to over-exalt her as a poet. For she shows these qualities of sensitiveness and intelligence, in dealing with matters of deep and intimate concern 
to men and women, which we expect from a poet, and which we often sadly miss in the work of her larger contemporaries 3 . 
POEMAS 
SONG

When I am dead, my dearest,

Sing no sad songs for me;

Plant thou no roses at my head,

Nor shady cypress tree:

Be the green grass above me

With showers and dewdrops wet:

And if thou wilt, remember,

And if thou wilt, forget.

I shall not see the shadows,

I shall not feel the rain;

I shall not hear the nightingale

Sing on as if in pain:

And dreaming through the twilight

That doth not rise nor set,

Haply I may remember,

And haply may forget.

\section{REST}

O Earth, lie heavily upon her eyes;

Seal her sweet eyes weary of watching, Earth;

Lie close around her; leave no room for mirth

With its harsh laughter, nor for sound of sighs.

She hath no questions, she hath no replies,

Hushed in and curtained with a blessed dearth

Of all that irked her from the hour of birth;

With stillness that is almost Paradise.

Darkness more clear than noonday holdeth her,

Silence more musical than any song;

Even her very heart has ceased to stir:

Until the morning of Eternity

Her rest shall not begin nor end, but be;

And when she wakes she will not think it long.

\section{REMEMBER}

Remember me when I am gone away,

Gone far away into the silent land;

When you can no more hold me by the hand,

Nor I half turn to go yet turning stay.

Remember me when no more day by day

You tell me of our future that you planned:

Only remember me; you understand 


\section{CANCIÓN}

Cuando haya muerto, mi amor, no cantes triste por mí, siembres rosas en mi tumba, ni cipreses que den sombra: sé para mí verde hierba con rocio y aguaceros: y si es tu deseo, recuérdame, y si es tu deseo, olvídame.

No volveré a ver las sombras, ni sentiré ya la lluvia, ni oiré más al ruiseñor cantar de dolor transido: y soñando en el crepúsculo que ni llega ni se marcha, quizá pueda recordar y quizá pueda olvidar.

\section{DESCANSO}

¡Oh Tierra, cae violenta encima de sus ojos, sella sus dulces ojos de mirar haitos, Tierra; cae a ella pegada: no dejes que haya gozo con su inhumana risa, ni permitas suspiros. No va a preguntar ella, ni a contestar tampoco, silenciada, en mortaja, con la bendita ausencia de aquello que la angustia desde su nacimiento, con la tranquilidad que es casi el Paraíso.

La penumbra más clara que el mediodia la apresa, el silencio es más ritmico que cualquier canción fuera; hasta su corazón de latir ha dejado: hasta el amanecer era inmortal no tiene su descanso comienzo o fin: perdura y cuando ella despierte no meditará más.

\section{RECUERDO}

Recuérdame ya cuando yo me haya marchado; me haya marchado lejos a la silente tierra; cuando tú ya no puedas llevarme de la mano, ni me de media vuelta, sino que quede estática. que para aconsejar o rezar será tarde. Pero si me olvidaras, sólo por un momento, para luego después recordarme, no sufras: 
It will be late to counsel then or pray.

Yet if you should forget me for a while

And afterwards remember, do not grieve:

For if the darkness and corruption leave

A vestige of the thoughts than once I had,

Better by far you should forget and smile

Than that you should remember and be sad.

\section{ECHO}

Come to me in the silence of the night;

Come in the speaking silence of a dream;

Com with soft rounded cheeks and eyes as bright

As sunlight on a stream;

Come back in tears,

O memory, hope, love of finished years.

O dream how sweet, too sweet, too bitter sweet, Whose weakening should have been in Paradise, Where souls brimful of love abide and meet;

Where thirsting longing eyes

Watch the slow door

That opening, letting in, lets out no more.

Yet come to me in dreams, that I may live My very life again though cold in death:

Come back to me in dreams, that I may give

Pulse for pulse, breath for breath:

Speak low, lean low,

As long ago, my love, how long ago.

\section{A BIRTHDAY}

My heart is like a singing bird

Whose nest is in a watered shoot:

My heart is like an apple-tree

Whose boughs are bent with thickset fruit;

My heart is like a rainbow shell

That paddles in a halcyon sea;

My heart is gladder that all these

Because my love is come to me.

Raise me a dais of silk and down;

Hang it with vair and purple dyes;

Carve it in doves and pomegranates, 
Recuérdame ya cuando no puedas ya contarme ni hablarme del futuro que por los dos fraguaste: recuérdame tan sólo; tú puedes comprender cuando ya las tinieblas y la corrupción dejen un rastro del pensar que otrora hubo en mi mente, más a ti te valdría olvidar y sonreír que intentar recordarme para ponerte triste.

ECO

Ven a mí en el silencio de la noche profunda; vente con el silencio que en los sueños te habla; ven con mejillas dulces y ojos tan relucientes cual luz sobre el arroyo;

regresa aquíllorando, oh memoria, esperanza, amor de años marchitos.

¡Oh sueños, cuán dulces sois, tan dulces, tan amargos, su despertar debiera ser en el Paraíso, donde almas de amor plenas habitan y se encuentran; donde ojos nostálgicos miran la lenta puerta que al abrir deja entrar y salir jamás deja.

Pero ven a mí en sueños, para que vivir pueda de nuevo aún mi vida aunque helada en la muerte: vuelve hacia mí en sueños, para que pueda darte latidos y suspiros: habla quedo inclinándote, como tiempo ha, mi amor, como hace mucho tiempo.

UN CUMPLEAÑOS

Mi corazón es como un pájaro que canta cuyo nido está en un brote anegado: mi corazón es como el árbol del manzano cuyas ramas se doblan con las espesas frutas; mi corazón es como apeo del arco-iris que gusta chapotear en la mar apacible; mi corazón está más alegre que otros porque mi amor está hacia mí regresando.

Álzame un altar de seda y de plumas; cuélgalo con la piel de ardilla y tonos púrpuras; escúlpelo en palomas y también en granadas, 
And peacocks with a hundred eyes;

Work in it gold and silver grapes,

In leaves and silver fleurs-de-lys;

Because the birth of my life

Is come, my love is come to me.

UP-HILL

Does the road wind up-hill all the way?

Yes, to the very end.

Will the day's journey take the whole long day?

From morn to night, my friend.

But is there for the night a resting-place?

A roof for when the silow dark hours begin.

May not the darkness hide it from my face?

You cannot miss that inn.

Shall I meet other wayfarers at night?

Those who have gone before.

Then must I knock, or call when just in sight?

They will not keep you standing at that door.

Shall I find comfort, travel-sore and weak?

Of labour you shall find the sum.

Will there be beds for me and all who seek?

Yea, beds for all who come.

PASSING AWAY

Passing away, said the World, passing away:

Chances, beauty, and youth, sapped day by day:

Thy life never continueth in one stay.

Is the eye waxen dim, is the dark hair changing to grey

That hath no won neither laurel nor bay?

I shall clothe myself in Spring and bud in May:

Thou, root-striken, shalt not rebuild they decay

On my bosom for aye.

Then I answered: Yea.

Passing away, said my Soul, passing away:

With its burden of fear and hope, of labour and play,

Hearken what the past doth witness and say:

Rust in thy gold, a moth is in thine array,

A canker is in thy bud, thy leaf must decay. 
y en los pavos reales con cien enormes ojos; lábralo en las uvas doradas y plateadas, en las hojas y flores de lis argenteadas; mi nacer a la vida en este día ha llegado, mi amor viene hacia mí.

\section{CUESTA ARRIBA}

¿Serpentea el camino de continuo hacia arriba? Sí, y así hasta el final.

¿El viaje del día durará un día entero?

Del alba a la noche, amigo.

¿Acaso hay un lugar de descanso esta noche? Un techo para cuando la penumbra comience. ¿La oscuridad no puede ocultarlo a mis ojos? No pierdas tu refugio.

¿Me encontraré con otros peregrinos de noche? Aquellos que partieron antes que yo lo hiciera. Entonces, igolpear debo o presentarme hablando? No te dejarán ellos que estés de pie en la puerta.

¿Encontraré sosiego, tan agotado y débil?

De la ocupación diaria encontrarás plenitud.

¿Habrá para mí lechos y para los que busquen?

Sí, lechos habrá aqui para todo el que venga.

\section{DESAPARECER}

Pasar, expresó el Mundo, irse, desvanecerse: la suerte, la belleza, la juventud día a día: tu vida no está quieta en un solo lugar. ¿Se apaga ya tu vista, se torna el pelo gris sin haber conseguido elogios ni laureles? Me visto en primavera y echo brotes en mayo: tú, lleno de raíces, no evitarás su ruina por siempre en mi pecho.

Respondí entonces: sí.

Pasar, expresó mi Alma, irse, desvanecerse: Llena de miedo y ánimo, de trabajo y de ocio, oid lo que el pasado testifica y afirma:

atrófiate en tu oro, una polilla en tu hábito, una úlcera en tu brote, debe fenecer tu hoja. 
A midnight, at cockcrow, at morning, one certain day Lo the Bridegroom shall come and shall not delay;

Watch you and pray.

Then I answered: Yea.

Passing away, said my God, passing away:

Winter passeth after the long delay:

New grapes on the vine, new figs on the tender spray,

Turtle called turtle in Heaven's May.

Though I tarry, wait for $\mathrm{Me}$, trust $\mathrm{Me}$, watch and pray:

Arise, come away, night is past and lo it is day,

My love, My sister, My spouse, thou salt hear Me say.

Then I answered: Yea. 
A medianoche, al alba, por la mañana, un día ¡Ay! el novio vendrá, no se demorará;

Estate alerta y reza.

Respondi entonces: sí.

Pasar, dijo mi Dios, irse, desvanecerse:

pasa el invierno luego de la larga demora:

en la vid uva nueva, en el rocío higos nuevos,

en mayo la tortuga llamaba a otra tortuga.

Si me retraso, espérame, confia en Mí, mira y reza:

Levántate al dia, la noche ya ha pasado,

Mi amada, Mi hermana, Mi cónyuge, tú oirás.

Respondí entonces: sí.

\footnotetext{
'Jennings, E: A Choice of Christina Rossetfi's verse, Londres, Faber \& Faber, 1970, pág. 11.

${ }^{2}$ MacBeth, G. (ed.): The Penguin Book of Victorian Verse, Londres, Penguin Books Ltd., 1982 (1969), pág. 220.

${ }^{3}$ Messenger, N.P. \& Watson, J.R. (eds.), Victorian Poetry: "The City of Dreadful Nights" and Other Poems, Londres, Dent, 1974, pág. 114.
} 